\title{
RESTRICTING CLIMATIC CONDITIONS ON THE EASTERN DISTRIBUTION LIMIT OF EUROPEAN BEECH (FAGUS SYLVATICA) IN NORTH-EASTERN ROMANIA FOR THE MARCH - JUNE INTERVAL
}

\section{Dumitru Mihăilă ${ }^{1 *}$, Andrei Emil Briciư ${ }^{1}$, Cătălin Constantin Roibu $^{2}$, Petruț Ionel Bistricean ${ }^{1 \& 3^{* *}}$}

Key words: restrictive climate, eastern beech limit, north-eastern Romania, pluviometric deficit, growth index

\begin{abstract}
The meteo-climatic arguments for the eastern biogeographic limit of beech in Romania are of particular interest to forestry, but also to geographers and climatologists. This limit marks the transition from the temperate humid climate of Western and Central Europe to the temperate continental climate of Eastern Europe. Our paper provides improved knowledge on climatic conditions that restrict the longitudinal distribution of beech at temperate latitudes in north-eastern Romania. Results show that rainfall scarcity and high temperature in the March-June interval, added to temperature drop below the freezing point in April-June are the main climatic conditions that limit beech expansion eastward of this biogeographic limit.
\end{abstract}

\section{Introduction}

The transition between Suceava and Bârladului plateaus and Moldova Plain is characterized by a gradual, eastward change from forest to foreststeppe and steppe.

In this region, European beech (Fagus sylvatica) occurs at the eastern limit of its natural distribution. Although old and vigorous beech trees are frequently found in the forests of this area (e.g., a 417-year-old beech-tree was identified in the Humosu - Iași Reserve; Roibu, 2010, Roibu, et al., 2017), the species is subject to restrictive climatic conditions specific to north-eastern Romania.

Temperature drop below the freezing point at the beginning of the annual vegetation growth cycle negatively affects beech growth rings.

${ }^{1}$ Department of Geography, "Stefan cel Mare" University of Suceava, Romania

${ }^{2}$ Forest Biometrics Laboratory, "Stefan cel Mare" University of Suceava, Romania

${ }^{3}$ Regional Meteorological Center of Moldova, National Meteorological Administration, Romania

*email: dumitrum@atlas.usv.ro; ${ }^{* *}$ petricabistricean@gmail.com 
Furthermore, high temperatures favour increased evapotranspiration and have a negative effect on the growth and expansion of this species.

Water scarcity, manifested as drought, raises many economic and ecological issues (Mihăilă, 2006, Nedealcov, 2012). In this part of Europe drought occurs with increased frequency and duration, making the territories vulnerable (Alexandrov et al., 2010). The thermo-pluviometric prognoses show an increase in water shortage particularly during the vegetation season (Potop, 2011, Piticar et al., 2016, Mihăilă et al., 2017).

Dry and very hot summers and autumns are more frequent (Boroneanţ et al., 2013) and generally followed by cold, unstable winters with short-lived snow cover. Water shortage during the vegetation season leads to a lower bioaccumulation in forest ecosystems, which also lose their vitality (Dobbertin, 2005). Water shortage acts as a limiting factor on the eastern natural limit of beech. Beech development is optimum under temperate and wet climatic conditions and this species becomes increasingly sensitive to drought, as the climatic conditions at the limit of its eastern distribution area change (Bréda et al., 2006, Nahm et al., 2006, Kramer et al. 2010, Piticar et al., 2016, Mihăilă et al., 2017).

Dendrochronological research on beech trees has shown a positive correlation between the annual ring width and precipitation amount of the vegetation season (Dittmar et al., 2003, Fotelli et al., 2009, Roibu, 2010, Roibu et. al, 2017, Scharnweber et al., 2011).

The relationship between water shortage and tree radial growth is based on the monthly or seasonal precipitation amount (Michelot et al., 2012, Lebourgeois et al., 2005, Scharnweber et al., 2011).

Precipitation variability, characteristic of the areas with a continental transition climate, requires that the analysis of the temporal relationships between tree growth and moisture availability should be based on synthetic climatic indices at different temporal scales (Vicente-Serrano et al., 2012).

The Standardized Precipitation Index (SPI) has the ability to highlight the duration and intensity of precipitation deficit at different time scales (McKee et al., 1993). Rainfall deficit and high temperatures accentuate the negative consequences of climate on physiological processes of trees and accumulation of woody biomass. The standardized precipitationevapotranspiration index (SPEI) integrates potential evapotranspiration into rainfall deficit and can be successfully used in the climate-tree relationship analysis (Vicente-Serrano et al., 2010, Popa, Caisîn, 2015).

Chira et al. noted in 2003 that beech decline occurred over successive drought years. Analysis of the de Martonne climatic index for the last 40 years 
indicated an increase in the frequency and duration of drought in the forest belt of the Suceava hilly area.

Chira et al. (2005) showed that the 1999-2000 drought was strongly felt in the eastern and north-eastern part of Romania and contributed, along with other climatic factors, to the phenomenon of beech debilitation (drying) in the old-growth (over 100 years old), pure and highly productive forest stands. Other climatic factors including late frosts and hail weaken the resistance of beech (large hail causes growth similar to beech cancer) and favour the occurrence of Nectria infections (Chira et al., 2005).

Negative correlations with high temperature during the vegetation season were also noted. Climate warming is considered a promoting factor for beech debilitation (Chira et al., 2005).

\section{Study area}

The eastern limit of the distribution of beech forests in north-eastern Romania overlaps the contact line between the Moldova Plain and the Suceava Plateau in the west, the Bârlad Plateau in the south respectively. Practically, this diffuse or transition area between forest and forest-steppe is largely identified in the physical-geographic contact subunits between the Moldova hilly plain and the two plateau areas (Suceava in the west, Bârlad in the south), which are known in the Romanian geography under the name of cuestas: Ibănești Cuesta (located in the north of the Moldova Plain), Moldavă Cuesta (between Moldova Plain and Suceava Plateau) and Iași Cuesta (between Moldova Plain and Bârlad Plateau). Due to specific physico-geographic and socio-economic conditions, only patches of compact beech forests can still be found today in this area, particularly on higher elevation, more isolated landforms.

The mathematical position in terms of latitude (the study area is located between $48^{\circ} 15^{\prime} \mathrm{N}$ and $\left.47^{\circ} \mathrm{N}\right)$ and longitude $\left(25^{\circ} 4^{\prime} \mathrm{E}-27^{\circ} 55^{\prime} \mathrm{E}\right)$, along with its geographical position within Europe (in the centre of the continent, with low oceanic influences) and Romania (north-eastern part) shape the climate of the study area with temperate (annual mean global radiation on a horizontal surface is around $115 \mathrm{Kcal} / \mathrm{cm}^{2}$; the existence of four seasons) and transition characteristics (from the oceanic climate, which becomes increasingly evident as we move westward from the Eastern Carpathian Mountain range, to the continental climate, typical of Eastern Europe; from the sub-Mediterranean climatic influences frequent in the southern parts of Romania, to the Baltic and boreal characteristics often present in northern Romania).

- Permanent, semi-permanent or seasonal high-pressure (e.g., Azores High, Siberian High, Scandinavian-Baltic High, Greenland High) and low- 
pressure atmospheric systems (e.g., Icelandic Low, Mediterranean Low, Eurasian Low) impose a high degree of variability on climatic elements (especially temperature, precipitation, wind parameters) and phenomena, a feature specific to climates with an enhanced degree of continentality.

- Among the regional and local background features of the studied area, the following are climatically relevant:

a) Eastern Carpathians, which form an orographic barrier in the direction of wetter air masses coming from Western Europe; oceanic air masses generate rain on the western slopes of the Eastern Carpathian range and foehn on the eastern slopes towards Suceava Plateau and Moldova Sub-Carpathians (the average difference in elevation between Obcina Mare Peaks and Suceava Plateau is $800-1000 \mathrm{~m}$ a.s.1.);

b) the study area is widely open towards north, northeast and east, in the direction of Baltic, Nordic and Continental air masses (main river valleys and mountain ranges are arranged northwest - southeast, which facilitates the advection of air masses from NW and SE);

c) the elevation difference of 150-300 m between Suceava / Bârlad plateaus and the Moldova Plain, evident in the transition area between the two landform types (the northern, western and southern hilly marginal cuestas of the Jijia Plain), which favors a second foehnization (of lower intensity but relevant with regard to rainfall occurrence) of the western air masses in their advection towards eastern Europe.

Next to their role in precipitation distribution patterns, the two orographic barriers block winter and spring advections of polar continental air masses towards western Europe, thus enhancing frost in the lowlands of northeastern Moldova and favoring prolonged thermal inversions and a longer persistence of the snow layer. In summer, under relative shelter conditions, temperature in the lower elevation areas of the Moldova Plateau reaches and frequently exceeds the heatwave threshold.

All these climatic conditions impose thermal and pluviometric restrictions on beech growth, which lead to a precarious balance in the proper succession of phenophases in the species, with more profound and frequent syncopes towards the east. This leads to increasingly unfavorable conditions for beech expansion in an increasingly continental climate.

\section{Data used}

The data from 13 meteorological stations and 57 pluviometric stations (Figure 1 and Table 1) were used to depict the climatic conditions for beech growth in the study area. Additional wood cores were extracted from beech trees in 6 dendrocronological series (Figure 1 and Table. 2). 
In order to understand the relationship between beech growth and climate on the eastern limit of the natural distribution for this species, 81 trees were sampled (13-33 samples / site) in 2005. 12 series were removed from the analysis due to their short length, low correlation with the mean series or crossdating problems due to false annual rings (Dittmar et al., 2003, Roibu, 2010, Roibu et al., 2017). More methodological details are presented in Roibu, 2010 and Roibu et al., 2017.

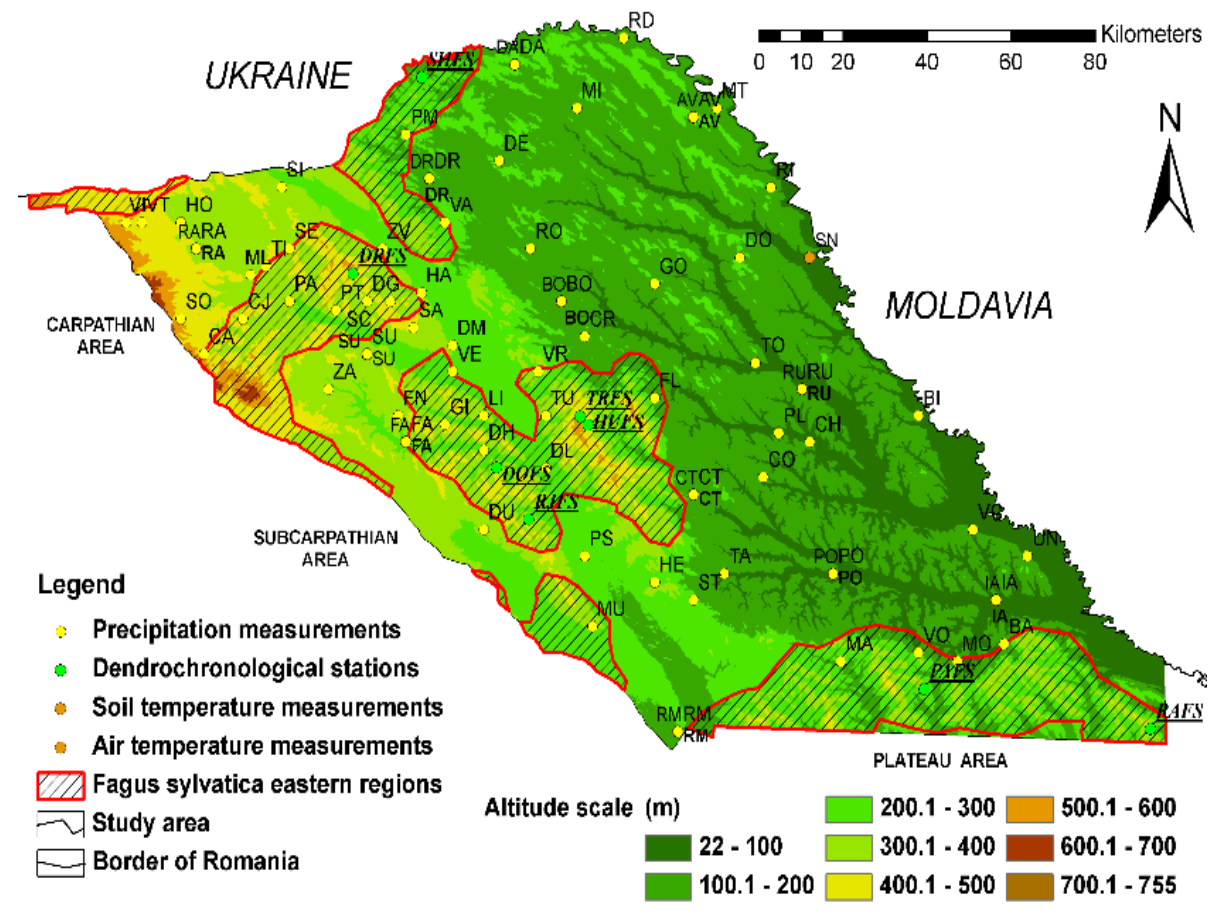

Figure 1. Geographic location of the eastern natural distribution limit of beech in north-eastern Romania; filled circles show the position of meteorological, pluviometric and dendrochronological series where data was obtained for climate characterization.

The meteorological data for climatic parameters relevant to the ecological conditions of beech growth span the 1961-2010 time interval; other parameters such as trends in climatic variables or water balance are available for a longer interval, i.e., 1961-2017. 
Table 1. Attributes (station code, name, mathematical coordinates and elevation) of the meteorological and pluviometric stations in north-eastern Romania located near the eastern beech limit.

\begin{tabular}{|c|c|c|c|c|c|c|c|c|c|c|c|}
\hline 只 & ํํㅇ & $\begin{array}{l}\text { 总 } \\
\text { 䊦 }\end{array}$ & 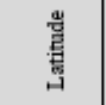 & 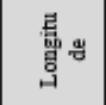 & 严园 & 豆 & छั & $\begin{array}{l}\text { 昫 } \\
\text { 曾 }\end{array}$ & 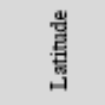 & 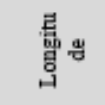 & 曾 \\
\hline 1 & $A D$ & Adâncata & 47.73333 & 26.3 & 400 & 36 & MU & \begin{tabular}{|c|} 
Muncelu de \\
Sus
\end{tabular} & 47.11667 & 26.73333 & 325 \\
\hline 2 & $\mathrm{AV}$ & Avrămeni & 48.08333 & \begin{tabular}{|l|}
26.95 \\
\end{tabular} & 240 & 37 & PA & Părhăutịi & 47.73333 & 26.08333 & 403 \\
\hline 3 & BA & Bâmova & 47.08333 & 27.61667 & 360 & 38 & PS & Paşcani & 47.25 & 26.71667 & 248 \\
\hline 4 & BI & Bivolari & 47.51667 & 27.43333 & 55 & 39 & PT & Pătrăuti & 47.71667 & 26.18333 & 350 \\
\hline 5 & $\mathrm{BO}$ & Botogani & 47.73333 & 26.66667 & 170 & 40 & PL & Plugari & 47.48333 & 27.13333 & 80 \\
\hline 6 & $\mathrm{CA}$ & Cacica & 47.63333 & 25.9 & 255 & 41 & PO & Podu Iloaiei & 47.21667 & 27.25 & 90 \\
\hline 7 & $\mathrm{CJ}$ & Cajvana & 47.7 & 25.98333 & 410 & 42 & PM & Pomârla & 48.05 & 26.33333 & 190 \\
\hline 8 & $\mathrm{CH}$ & Chișcăreni & 47.46667 & 27.2 & 60 & 43 & RA & Rădăuti & 47.83333 & 25.88333 & 389 \\
\hline 9 & $\mathrm{CO}$ & $\begin{array}{c}\text { Coamele } \\
\text { Caprei }\end{array}$ & 47.4 & 27.1 & 165 & 44 & $\mathrm{RD}$ & $\begin{array}{l}\text { Rădăuți } \\
\text { Prut }\end{array}$ & 48.23333 & 26.8 & 101 \\
\hline 10 & $\mathrm{CT}$ & Cotmari & 47.36667 & 26.95 & 289 & 45 & $\mathrm{RU}$ & Răuseni & 47.56667 & 27.18333 & 62 \\
\hline 11 & $\mathrm{CR}$ & Cristești & 47.66667 & 26.71667 & 110 & 46 & RI & Ripiceni & 47.95 & 27.11667 & 84 \\
\hline 12 & $\mathrm{DA}$ & Darabani & 48.18333 & 26.6 & 200 & 47 & RO & Roma & 47.83333 & 26.6 & 105 \\
\hline 13 & DO & Dobârceni & 47.81667 & 27.05 & 130 & 48 & $\mathrm{RM}$ & Roman & 46.91667 & 26.91667 & 216 \\
\hline 14 & $\mathrm{DL}$ & Dolhasca & 47.41667 & 26.63333 & 230 & 49 & SA & Salcea & 47.68333 & 26.35 & 405 \\
\hline 15 & $\mathrm{DH}$ & Dolheggti & 47.5 & 27.51667 & 280 & 50 & $\mathrm{SC}$ & Şcheia & 47.666 & 26.2 & 350 \\
\hline 16 & DR & Dorohoi & 47.96667 & 26.38333 & 197 & 51 & SE & Șerbăuti & 47.83333 & 26.08333 & 375 \\
\hline 17 & DG & Dragomima & 47.73333 & 26.25 & 315 & 52 & SI & Siret & 47.95 & 26.06667 & 300 \\
\hline 18 & $\mathrm{DU}$ & Drăgugeni & 47.3 & 26.5 & 315 & 53 & $\mathrm{SO}$ & Solca & 47.7 & 25.85 & 390 \\
\hline 19 & DM & Dumbrăveni & 47.65 & 26.43333 & 300 & 54 & SN & $\begin{array}{c}\text { Stânca } \\
\text { Costeşti }\end{array}$ & 47.81667 & 27.2 & 70 \\
\hline 20 & $\mathrm{DE}$ & Dumeni & 48 & 26.53333 & 180 & 55 & ST & Strunga & 47.16667 & 26.95 & 225 \\
\hline 21 & FA & Fălticeni & 47.46667 & \begin{tabular}{|l|}
26.33333 \\
\end{tabular} & 348 & 56 & SU & Suceava & 47.63333 & 26.25 & 352 \\
\hline 22 & FN & Fåntânele & 47.51667 & 26.31667 & 250 & 57 & TA & $\begin{array}{l}\text { Tárgu } \\
\text { Frumos }\end{array}$ & 47.21667 & 27.01667 & 90 \\
\hline 23 & $\mathrm{FL}$ & Flămânzi & 47.55 & 26.86667 & 158 & 58 & TI & Tibeni & 47.8 & 26.03333 & 319 \\
\hline 24 & GI & Giurgestti & 47.5 & 26.41667 & 354 & 59 & TO & Todireni & 47.61667 & 27.08333 & 57 \\
\hline 25 & GO & Gorbănegti & 47.76667 & 26.86667 & 120 & 60 & $\mathrm{TU}$ & Tudora & 47.51667 & 26.63333 & 270 \\
\hline 26 & $\mathrm{HA}$ & Hântesti & 47.75 & 26.36667 & 300 & 61 & UN & Ungheni & 47.25 & 27.66667 & 35 \\
\hline 27 & $\mathrm{HE}$ & Heleşteni & 47.2 & 26.86667 & 275 & 62 & VA & Văculesti & 47.88333 & 26.41667 & 220 \\
\hline 28 & HO & $\begin{array}{c}\text { Horodnic } \\
\text { de Jog }\end{array}$ & 47.88333 & 25.85 & 387 & 63 & VE & Verești & 47.6 & 26.43333 & 290 \\
\hline 29 & IA & Iaqi & 47.16667 & 27.6 & 100 & 64 & VI & $\begin{array}{l}\text { Vicovul } \\
\text { de Jos }\end{array}$ & 47.88333 & 25.73333 & 435 \\
\hline 30 & LI & Liteni & 47.51667 & \begin{tabular}{|l|}
26.5 \\
\end{tabular} & 315 & 65 & VC & Victoria & 47.3 & 27.55 & 42 \\
\hline 31 & MA & Mădârjac & 47.05 & 27.26667 & 250 & 66 & VO & Voinesti & 47.06667 & 27.43333 & 125 \\
\hline 32 & MI & Mileanca & 48.1 & \begin{tabular}{|l|}
26.7 \\
\end{tabular} & 145 & 67 & VT & Voitinel & 47.88333 & 25.76667 & 440 \\
\hline 33 & MI & Milișăuţi & 47.78333 & 26 & 325 & 68 & VR & Vorona & 47.6 & 26.61667 & 260 \\
\hline 34 & MT & Mitoc & 48.1 & 27 & 95 & 69 & $\mathrm{ZA}$ & Zaharegti & 47.56667 & 26.16667 & 315 \\
\hline 35 & MO & Mogosegti & 47.05 & 27.51667 & 150 & 70 & $\mathrm{ZV}$ & Zvoriqtea & 47.83333 & 26.28333 & 302 \\
\hline
\end{tabular}


Table 2. Attributes (station code, name, the mathematical coordinates and elevation) of the dendrochronological series for stations located on the eastern beech limit in northeastern Romania. Details of the relationships between beech growth and climate, as revealed by the dendrochronological series (extracted from Roibu, 2010).

\begin{tabular}{|c|c|c|c|c|c|c|}
\hline & $\begin{array}{c}\text { Dolhești } \\
\text { Series } \\
\text { DOFS } \\
47.418161 \\
\mathrm{~N} \\
26.52796 \mathrm{E} \\
450 \mathrm{~m} \text { a.s.l. } \\
\end{array}$ & $\begin{array}{c}\text { Dragomirn } \\
\text { a Series } \\
\text { DRFS } \\
47.786521 \\
\mathrm{~N} \\
26.22032 \\
469 \mathrm{~m} \text { a.s.l. }\end{array}$ & $\begin{array}{c}\text { Humosu } \\
\text { Series } \\
\text { HUFS } \\
47.498898 \\
\mathrm{~N} \\
26.72381 \mathrm{E} \\
456 \mathrm{~m} \text { a.s.l. }\end{array}$ & $\begin{array}{c}\text { Ruja Series } \\
\text { RJFS } \\
47.319427 \\
\mathrm{~N} \\
26.59739 \mathrm{E} \\
450 \mathrm{~m} \text { a.s.l. }\end{array}$ & $\begin{array}{c}\text { Stuhoasa } \\
\text { Series } \\
\text { SHFS } \\
48.158761 \\
\mathrm{~N} \\
26.36752 \mathrm{E} \\
214 \mathrm{~m} \text { a.s.1. }\end{array}$ & $\begin{array}{c}\text { Trei Pietre } \\
\text { Series } \\
\text { TRFS } \\
47.515159 \\
\mathrm{~N} \\
26.70764 \mathrm{E} \\
483 \mathrm{~m} \text { a.s.l. }\end{array}$ \\
\hline $\begin{array}{c}\text { Average length of } \\
\text { tree-ring samples } \\
\text { (years) }\end{array}$ & $\begin{array}{c}112 \pm 24 \\
(101-147) \\
\end{array}$ & $\begin{array}{c}110 \pm 16 \\
(96-135)\end{array}$ & $\begin{array}{c}257 \pm 98 \\
(154-416) \\
\end{array}$ & $\begin{array}{c}156 \pm 3 \\
(145-156)\end{array}$ & $\begin{array}{c}108 \pm 15 \\
(93-146)\end{array}$ & $\begin{array}{c}76 \pm 37 \\
(60-178)\end{array}$ \\
\hline Time span (years) & $1861-2007$ & $1859-2007$ & $1592-2007$ & $1846-2005$ & $1862-2007$ & $1831-2008$ \\
\hline $\begin{array}{c}\text { Average radial } \\
\text { growth }\left(\mathrm{mm} \mathrm{yr}^{-1}\right)\end{array}$ & $0.71-6.47$ & $0.34-5.02$ & $0.16-4.11$ & $0.32-5.94$ & $0.38-7.72$ & $\begin{array}{c}0.71- \\
10.34 \\
\end{array}$ \\
\hline $\begin{array}{l}\text { First-order average } \\
\text { autocorrelation for } \\
\text { radial growth series }\end{array}$ & $0.64 \pm 0.19$ & $0.64 \pm 0.14$ & $0.61 \pm 0.16$ & $0.57 \pm 0.10$ & $0.66 \pm 0.06$ & $0.72 \pm 0.12$ \\
\hline $\begin{array}{c}\text { Average } \\
\text { autocorrelation for } \\
\text { standard growth } \\
\text { indices series }\end{array}$ & $0.38 \pm 0.20$ & $0.36 \pm 0.12$ & $0.44 \pm 0.18$ & $0.46 \pm 0.10$ & $0.36 \pm 0.06$ & $0.60 \pm 0.18$ \\
\hline $\begin{array}{c}\text { Average } \\
\text { autocorrelation for } \\
\text { residual } \\
\text { dendrochronologic } \\
\text { al series }\end{array}$ & $-0.02 \pm 0.06$ & $0.00 \pm 0.01$ & $-0.02 \pm 0.06$ & $0.00 \pm 0.01$ & $0.01 \pm 0.05$ & $0.04 \pm 0.07$ \\
\hline $\begin{array}{c}\text { Growth indices }> \\
\text { series average }+2 \sigma\end{array}$ & 1982,1997 & $\begin{array}{c}1970, \\
1982, \\
1988, \\
1997,2001 \\
\end{array}$ & $\begin{array}{c}1961,1970, \\
1975,1982, \\
1990\end{array}$ & $\begin{array}{c}1966,1970, \\
1975,1982, \\
1998\end{array}$ & $\begin{array}{l}1982,1988, \\
1997,2001\end{array}$ & 1975 \\
\hline $\begin{array}{c}\text { Growth indices }< \\
\text { series average }-2 \sigma\end{array}$ & $\begin{array}{c}1964,1968 \\
1983\end{array}$ & $\begin{array}{c}1964, \\
1968, \\
1972,1983\end{array}$ & $\begin{array}{c}1964,1968, \\
1987,1995, \\
2000,2003, \\
2007 \\
\end{array}$ & $\begin{array}{l}1964,1968, \\
1987,1996\end{array}$ & $\begin{array}{c}1964,1968, \\
1995,2000, \\
2003\end{array}$ & 1972,1987 \\
\hline
\end{tabular}

\section{Methods}

An 81 trees were sampled in 2005 (13-33 samples/site). The growth series were standardized to remove the biological trend and to maximize the climatic signal. Residual growth indices were used to quantify the climate-tree relationship (Roibu et al. 2017). For each site, we used monthly average precipitation measured at the nearest meteorological/pluviometric station, spanning the 1961-2005 interval. Correlations and relationships were derived between biometric indices and climatic parameters which contribute in varying proportions to the water balance matrix available for beech growth.

The current eastern limit of beech growth in north-eastern Romania shows some interesting climatic peculiarities for the interval March-June, which are important because during this interval beech is very sensitive to 
weather conditions. These climatic characteristics were more thoroughly approached through case studies, to depict the climatic reality relevant for beech growth. We synthesized the temporal trends in temperature and precipitation, as resulting from climatic data. All these analysis approaches revealed key climate features influencing beech growth in the study area.

The growth indices were correlated with March-June (M-J) air/soil temperature and precipitation spanning the 1961-2005 interval. Studies have shown that this period of the year is of particular relevance to climatic requirements of beech (e.g., Roibu, 2010, Roibu et al., 2017). On the eastern limit of beech distribution in north-eastern Romania, statistically significant negative coefficients were obtained between temperature drops below $0^{\circ} \mathrm{C}$ in the April-June (A-J) interval and the dendroclimatological response of beech; conversely, statistically significant positive coefficients were obtained between precipitation amounts in the M-J interval and beech response. Water deficiency in the M-J interval can influence significant the growth processes. Correlations and relationships were thus derived between growth indices and climatic parameters that contribute in varying proportions to the heat balance and water availability matrix for beech growth.

Temperature and precipitation maps were constructed during 3 major stages using known GIS techniques. We used the data from 11 stations for soil temperature, 13 for air temperature and 69 for precipitation. Ordinary kriging interpolation was one of the methods used. Kriging has also been used successfully in other meteorological studies (Venkatram, 1988, Boer and Lambert, 2001, Alsamamra et al., 2009).

\section{Results}

Many studies have already shown that beech is strongly influenced by climatic factors (temperature and precipitation). For north-eastern Romania, Roibu (2010) and Roibu et al. (2017) demonstrated that temperature and precipitation in the M-J interval of each year are very important for the ecological cycle of this species (Table 3 ).

The present study also focuses on the M-J time interval of the year, also considering the temperature-precipitation interaction from the second half of the previous year, which is very important for the bioaccumulation process in beech species, for its territorial distribution respectively.

Average monthly temperature. In the M-J interval, average soil surface temperature increased from 1.1 and $3.2^{\circ} \mathrm{C}$ in March at Rădăuţi and Podu Iloaiei, to 20.5 and $24.5^{\circ} \mathrm{C}$ in June at Rădăuţi and Podu Iloaiei respectively Figure 2a, with a mean thermal jump of over $20.1^{\circ} \mathrm{C}$. 
Similarly, the average monthly air temperature (Figure $2 b$ ) increased from $1.3^{\circ} \mathrm{C}$ in March at Rădăuţi, $3.1^{\circ} \mathrm{C}$ at Podu Iloaiei and Iași respectively, to $19.5^{\circ} \mathrm{C}$ in June at Podu Iloaiei, with a mean thermal jump of $16^{\circ} \mathrm{C}$, i.e., $4^{\circ} \mathrm{C}$ lower than the thermal jump on the soil surface.

Table. 3 Correlation coefficients between tree ring index and main climatic parameters

(extracted from Roibu et al., 2017).

\begin{tabular}{|c|c|c|c|c|c|c|c|c|c|c|c|c|c|c|c|c|}
\hline \multirow{2}{*}{$\begin{array}{c}\text { Dendro } \\
\text { series }\end{array}$} & \multicolumn{8}{|c|}{ Previous year } & \multicolumn{8}{|c|}{ Current year } \\
\hline & $\mathrm{m}$ & $\mathrm{j}$ & $\mathrm{j}$ & $\mathrm{a}$ & $\mathrm{s}$ & o & $\mathrm{n}$ & $\mathrm{d}$ & $\mathrm{J}$ & $\mathrm{F}$ & $\mathrm{M}$ & $\mathrm{A}$ & $\mathrm{M}$ & $\mathrm{J}$ & $\mathrm{J}$ & $\mathrm{A}$ \\
\hline \multicolumn{17}{|c|}{ Precipitation } \\
\hline RIFS & & 0.23 & & & & & & & & & & 0.27 & 0.36 & & & \\
\hline$D R F S$ & & & & & & & & & & & & 0.30 & & & & \\
\hline RUFS & & & 0.37 & & & & 0.27 & & & & & 0.22 & 0.32 & 25 & & 0.22 \\
\hline HUFS & & & 0.26 & & & & & & & & & 0.33 & 0.27 & & & \\
\hline DOFS & & & & & 0.21 & & & & & & & 0.27 & 0.29 & & & \\
\hline STFS & & & & & 0.21 & & 0.23 & & & & & 0.35 & 0.27 & & & \\
\hline \multicolumn{17}{|c|}{ Mean temperature } \\
\hline RIFS & & -0.29 & -0.24 & & & & 0.24 & & & & & & -0.27 & -0.31 & & \\
\hline$D R F S$ & & & -0.30 & & & & & & & & & & & -0.32 & & \\
\hline RUFS & & -0.26 & -0.29 & -0.22 & -0.24 & & & & & & & & & -0.37 & & \\
\hline HUFS & & -0.25 & -0.39 & & -0.19 & & & 0.21 & & & & & & -0.32 & & \\
\hline DOFS & & & -0.29 & & -0.29 & & & & & & & -0.22 & & -0.38 & & \\
\hline STFS & & & -0.23 & -0.24 & -0.26 & & & 0.25 & & & & -0.25 & & -0.33 & & \\
\hline
\end{tabular}

On a monthly basis, the average temperature in the M-J interval shows slight increases $\left(3-6^{\circ} \mathrm{C}\right.$ for soil surface, $3-4^{\circ} \mathrm{C}$ for air) both in the NW-SE and W-E directions $\left(2-3^{\circ} \mathrm{C}\right.$ for both soil surface and air $)$ - Figure $3 \mathrm{a}-\mathrm{b}$; $4 \mathrm{a}-\mathrm{b}$.
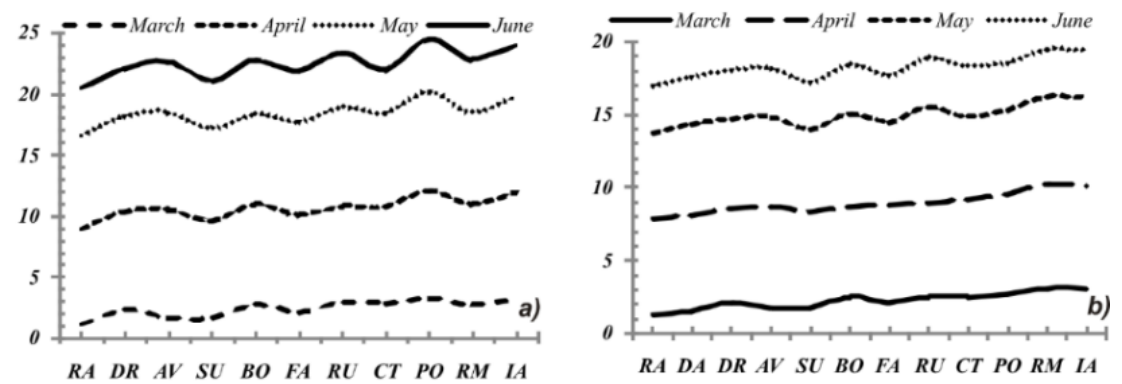

Figure 2. Variability of average monthly a) soil surface and b) air temperature (March - June) on the eastern beech limit and the surrounding area (1960-2010). Abbreviations in the figure refer to measurement stations included in Table 1.

These situations can be explained by the decrease in elevation from NW and $\mathrm{W}$ towards SE and $\mathrm{E}$, and also by the changes in the active surface 
characteristics (reduction of the forest cover, increase in the areas covered by forest-steppe and steppe vegetation etc.)

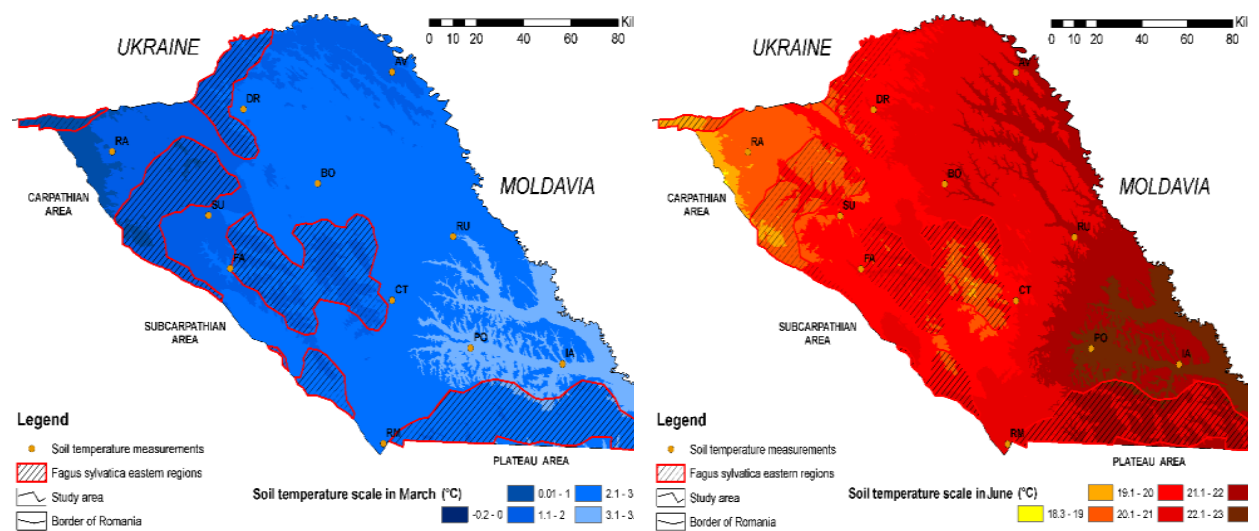

Figure 3 Spatial distribution of average soil surface temperature in a) March, b) June.

These situations can be explained by the decrease in elevation from NW and $\mathrm{W}$ towards $\mathrm{SE}$ and $\mathrm{E}$, and also by the changes in the active surface characteristics (reduction of the forest cover, increase in the areas covered by forest-steppe and steppe vegetation etc.).

Temperature jumps on both soil surface and air $\left(20^{\circ}\right.$ and $16^{\circ} \mathrm{C}$ respectively) show that the phaenological stages of beech are forced to develop faster than in cooler climates with moderate temperature differences.

Highest maximum temperature analyzed annually for the M-J interval. The maximum soil surface temperature in the study area was $36.0^{\circ} \mathrm{C}$ in March at Rădăuţi, and $65.0^{\circ} \mathrm{C}$ in June at Iași. The average temperature jump of the monthly maxima in soil surface temperature in the M-J interval was around $20^{\circ} \mathrm{C}$ (from $40.4^{\circ} \mathrm{C}$ in March to $59.9^{\circ} \mathrm{C}$ in June). Conversely, maximum air temperature was between $24.3^{\circ} \mathrm{C}$ in March at Suceava and $36.4^{\circ} \mathrm{C}$ in June at Dorohoi. For thermal jumps in air temperature, the increase is less prominent (from $25.5^{\circ} \mathrm{C}$ in March, to $35.2^{\circ} \mathrm{C}$ in June). Such high amplitude jumps in soil and air temperature are not beneficial for beech growth. 


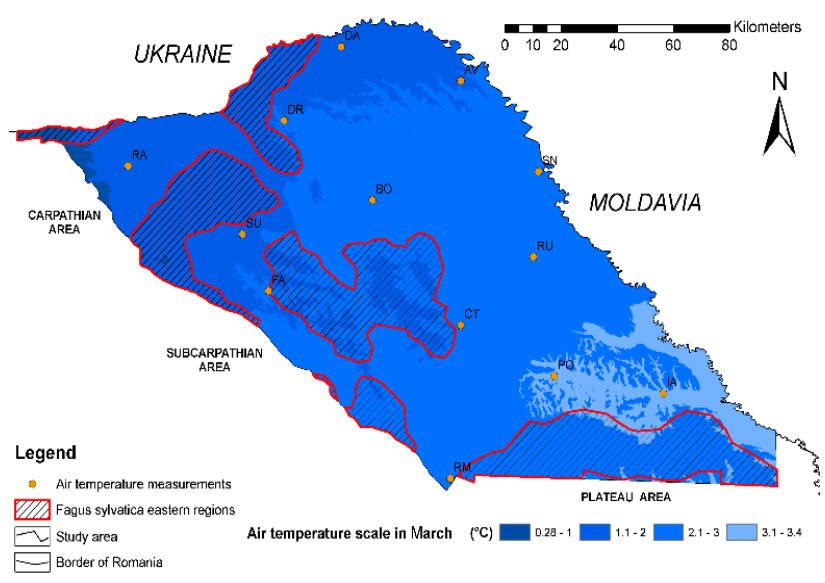

a.

Lowest minimum temperature analyzed annually for the M-J interval. The lowest temperature values recorded on the soil surface and air are regarded as very important for the onset of the beech vegetative cycle.

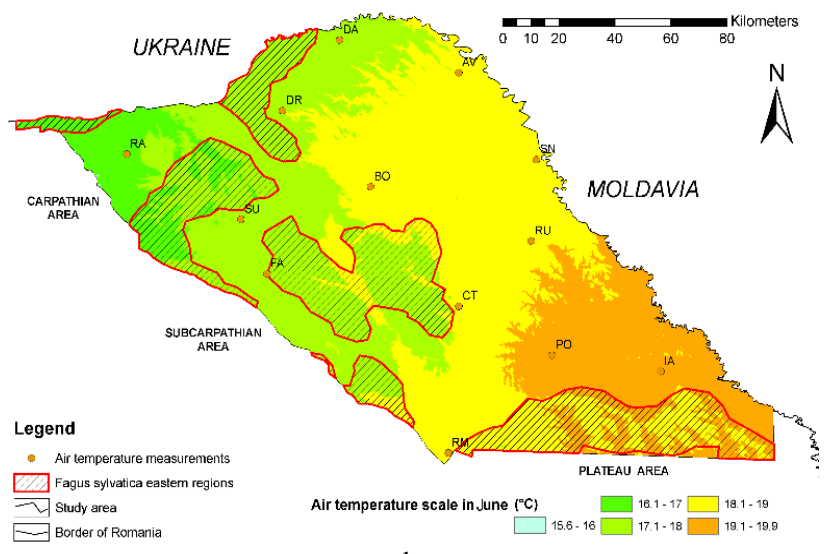

b.

Figure 4 Spatial distribution of average air temperature in a) March and b) June.

In our study area (Suceava Plateau, Moldova Plain, northern part of Siret Valley, northern Bârlad Plateau), the soil surface temperature dropped in March to $-29.0^{\circ} \mathrm{C}$ at Suceava, $-23.4^{\circ} \mathrm{C}$ at Cotnari, whereas in June to $0.0^{\circ} \mathrm{C}$ at Rădăuţi and $5.0^{\circ} \mathrm{C}$ at Podu Iloaiei. By spatially averaging the lowest temperature values, we noted that these averages dropped to $-25.7^{\circ} \mathrm{C}$ in March and to $1.8^{\circ} \mathrm{C}$ in June. 
Intra-monthly variability of the lowest minimum soil surface and air temperature for the eastern beech limit is shown in Figure 5a. Similar values also characterize the wider geographic territory in which our study area is located (i.e., $-25.0^{\circ} \mathrm{C}$ in March and $1.6^{\circ} \mathrm{C}$ in June).
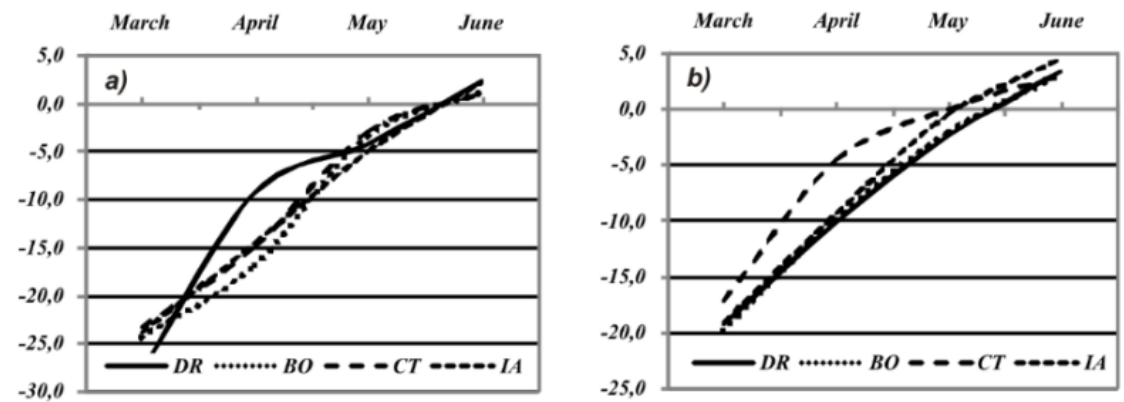

Figure 5. Intra-monthly variability (March - June) of the minimum (a) soil surface and (b) air temperature at the meteorological stations located on the eastern beech limit (north-eastern Romania, 1960-2010). Abbreviations in the figure refer to stations included in Table 1.

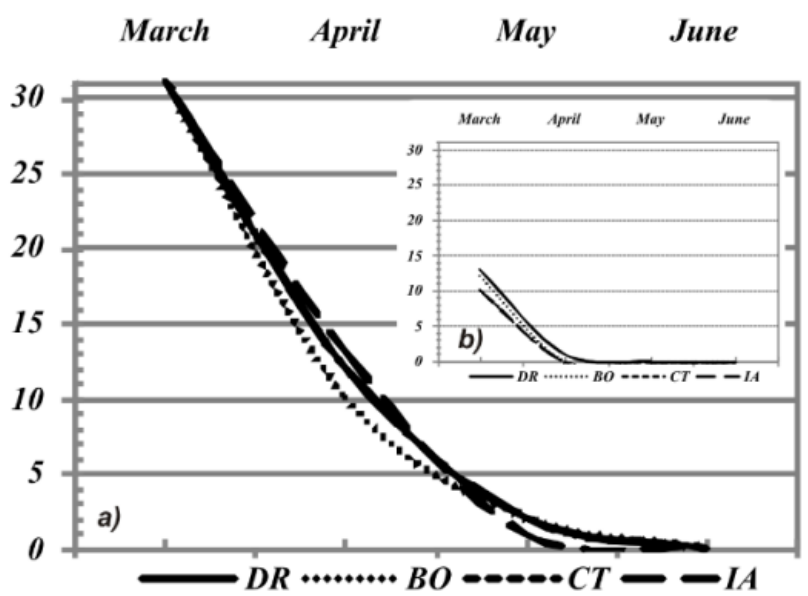

Figure 6. Intra-monthly variability of the maximum number of (a) freezing nights (minimum air temperature $\leq 0^{\circ} \mathrm{C}$ ) and (b) frost nights (maximum air temperature $\leq$ $10^{\circ} \mathrm{C}$ ) in the M-J interval at the meteorological stations located near the eastern beech limit, north-eastern Romania (1960-2010). Abbreviations in the figure refer to measurement stations included in Table 1. 
Regarding lowest minimum air temperatures, these ranged between $24.4^{\circ} \mathrm{C}$ at Rădăuţi, $-17.2^{\circ} \mathrm{C}$ at Cotnari in March, and between $1.6^{\circ} \mathrm{C}$ at Rădăuţi, $4.5^{\circ} \mathrm{C}$ at Iași in June respectively. Minimum air temperature averaged across our study area from the four abovementioned stations ranged from $-20.1{ }^{\circ} \mathrm{C}$ in March to $3,2^{\circ} \mathrm{C}$ in June. For adjacent areas, minimum air temperature was between $-19.0^{\circ} \mathrm{C}$ in March and $3.5^{\circ} \mathrm{C}$ in June - figure $5 \mathrm{~b}$. It should be noted, however, that both the lowest soil surface temperatures and air temperatures dropped below $0^{\circ} \mathrm{C}$ in May and were close to $0^{\circ} \mathrm{C}$ in June; such values can impact beech vegetative cycle to a great extent, which is also visible in the characteristics of its annual growth rings.

Soil and air freezing at the eastern beech limit is another phenomenon that can damage beech phenophases in April and particularly in May (Figure $6 a)$.

A temperature parameter indicating unfavorable weather conditions for beech is the monthly number of frost nights. For our study area, frost nights reached a maximum in March during the M-J interval (13 nights at Dorohoi, 10 nights at Cotnari and Iași). At Dorohoi station (but also at the other analyzed locations), statistical data show that frost nights can also occur in May - Figure $6 b$.

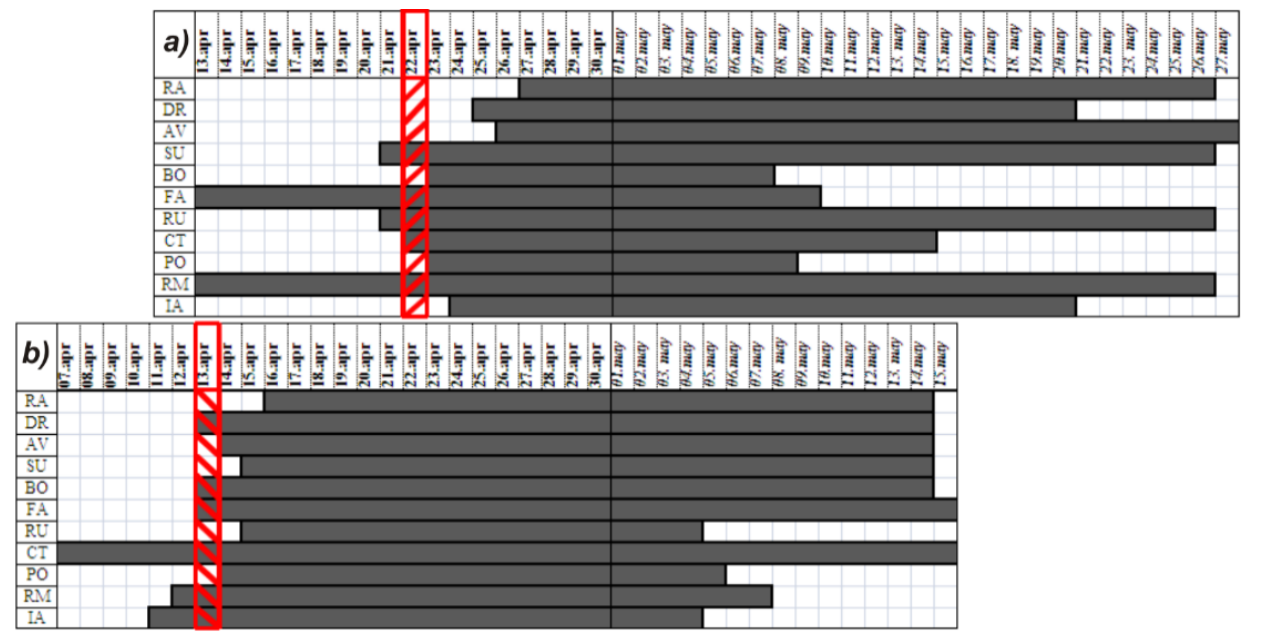

Figure 7 Spring climatic risk interval (dark background) for a) soil surface frost and b) air frost, at the meteorological stations located near the eastern beech limit in NE Romania (1960-2010); the red hatched rectangle marks the average dates of the last soil surface and air frosts. 
Measurement data and statistical analysis show that in the wider geographical areas adjacent to our study area the last soil surface freezing occurs on average on April 22 (Figure 7a), whereas the last air freezing on April 13 (Figure 7b).

Depending on the local particularities of the active surface, the last soil surface frost occurred until the end of May (27 May at Avrămeni, 26 May at other four locations) - Figure 7a. In what concerns air frost, it was recorded until mid-May (15 May at Fălticeni and Cotnari) - Figure 7b. These late frosts, even if of low intensity, can cause frostbite in the foliage, branches and annual growth rings in beech species.

Research conducted at Dorohoi and Iași (Mihăilă, 2006) which are located on the eastern beech limit, shows that both air and soil surface frosts can be of high intensity in March, of moderate intensity in April, whereas in May only low intensity frosts occur (Table 4). For beech, high intensity or very late frosts cause foliar damage and severe declines (up to $50 \%$ ) in biomass production in the following year (Awaya et al., 2009).

The negative impacts of frequent temperature drops below the freezing point in the M-J interval were observed for most of the analyzed dendrochronological series. The negative response of beech in relation to temperature decrease below the freezing point, especially in April, was also noted for other dendrochronological series in Central and Eastern Europe (Dittmar et al., 2003, Roibu et. al, 2017) and Italy (Biondi and Visani, 1996, Piovensan et al., 2008).

Table 4 Monthly number of frost days with varying degrees of intensity at Dorohoi and Iași (1960-2000) - extracted from Mihăilă (2006).

\begin{tabular}{|c|c|c|c|c|c|c|c|c|c|c|c|c|c|c|c|c|}
\hline \multirow[b]{3}{*}{ Month } & \multicolumn{8}{|c|}{ Dorohoi } & \multicolumn{8}{|c|}{ Iași } \\
\hline & \multicolumn{4}{|c|}{ air } & \multicolumn{4}{|c|}{ soil surface } & \multicolumn{4}{|c|}{ air } & \multicolumn{4}{|c|}{ soil surface } \\
\hline & M & $\mathbf{A}$ & $\mathbf{M}$ & I & $\mathbf{M}$ & $\mathbf{A}$ & M & I & $\mathbf{M}$ & $\mathbf{A}$ & $\mathbf{M}$ & I & M & $\mathbf{A}$ & $\mathbf{M}$ & I \\
\hline $\begin{array}{c}\mathrm{W} \text { (weak) } \\
0.0 \div-5.0^{\circ} \mathrm{C}\end{array}$ & 13.5 & 3.1 & 0.1 & - & 14.3 & 6.3 & 0.4 & - & 11.8 & 6.4 & 0.5 & - & 16 & 6.4 & 0.5 & - \\
\hline $\begin{array}{l}\mathrm{M} \text { (moderate) } \\
-5.1 \div-15.0^{\circ} \mathrm{C}\end{array}$ & 5 & - & - & - & 7.9 & 0.3 & - & - & 3.9 & 0.2 & - & - & 5.4 & 0.2 & - & - \\
\hline $\begin{array}{c}\mathrm{S} \text { (strong) } \\
-15.1 \div-30.0^{\circ} \mathrm{C}\end{array}$ & 0.4 & - & - & - & 1.2 & - & - & - & 0.2 & - & - & - & 1.4 & & - & - \\
\hline
\end{tabular}

All these constraints imposed by temperature occur against the background of a regional increase in annual and monthly air temperature (Table 5).

The highest temperature rise in the 1961-2017 interval was recorded for March, followed by June. The generalized increase in average temperature, either monthly or annual (around $2^{\circ} \mathrm{C}$ ), is strongly statistically significant, confirming previous findings (Mihăilă and Briciu, 2012; Potop et al., 2012; 
Piticar 2013; Mihăilă et.al., 2017). The regional temperature increase in the M$\mathrm{J}$ interval is associated with a high thermal variability and consistent negative temperature deviations from the mean, thus making beech species vulnerable at the beginning of the annual vegetation cycle.

Table 5 Monthly (M-J interval) and annual averages of the Sen's slope estimates for air temperature at several meteorological stations located near or on the eastern beech limit in north-eastern Romania (1961-2017). Sen's slope estimates were obtained by Mann Kendall test.

\begin{tabular}{cccccc}
\hline $\begin{array}{c}\text { Air temperature (Sen's } \\
\text { slope) }\end{array}$ & Rădăuți & Suceava & Botoșani & Cotnari & Iași \\
\hline M & $0.067^{* *}$ & $0.067^{* *}$ & $0.062^{* *}$ & $0.067^{* *}$ & $0.067^{* *}$ \\
A & $0.033^{*}$ & $0.033^{*}$ & $0.030^{+}$ & $0.045^{*}$ & $0.030^{+}$ \\
M & $0.029^{*}$ & $0.030^{*}$ & $0.029^{*}$ & $0.033^{*}$ & $0.033^{*}$ \\
$\mathrm{~J}$ & $0.042^{* * *}$ & $0.045^{* * *}$ & $0.041^{* * *}$ & $0.041^{* *}$ & $0.045^{* * *}$ \\
Annual & $0.037^{* * *}$ & $0.036^{* * *}$ & $0.031^{* * *}$ & $0.035^{* * *}$ & $0.035^{* * *}$ \\
\hline +significant at the 0.1 level; * significant at $0.05 ; * *$ significant at 0.01 ;** significant at 0.001 &
\end{tabular}

Atmospheric humidity, nebulosity and precipitation. Relative air humidity of the study area ranges spatially from 80 to $85 \%$ in March, and from 70 to $75 \%$ in June (monthly averages). An assessment of extreme relative humidity values during measurement hours highlights many aspects of excessive weather conditions, such as, for example, the case when the relative humidity can reach over-saturation, especially during the succession of atmospheric fronts. Hence, peak values of this parameter are of interest because they generate different categories of hydrometeors, depending on air temperature.

The absolute humidity minima between March and June frequently fall below the $20 \%$ threshold (15\% at Avrămeni on $21.03 .1974 ; 12 \%$ at Avrămeni on 13.04.1967; $15 \%$ at Darabani on 18.05.1994, 14\% at Darabani on 11.06.1995, etc.). The saturation deficit often reaches 20-24 hPa in March and $35-49 \mathrm{hPa}$ in June. These monthly relative humidity minima and saturation deficit maxima trigger dryness and atmospheric drought with negative consequences on European beech.

Monthly average values of total nebulosity are between 6.5 tenths - at Roman, 7.3 tenths - at Iași in March and 5.5 tenths at Roman, 6.1 tenths at Iași in June respectively. European beech prefers wet and cloudy conditions, as it is a shade-tolerant species. Consequently, low nebulosity is not a favorable factor for beech growth in north-eastern Romania, also considering that nebulosity values are directly linked to the amount of precipitation. Another stress factor for beech is the precipitation amount during spring and summer months.

In the wider region surrounding the study area, annual precipitation reaches $575.9 \mathrm{~mm}$ of water on average. The Suceava Plateau receives on 
average $597 \mathrm{~mm}$ precipitation annually (Tănasă, 2011) and Moldova Plain 552 mm (Mihăilă, 2006). In the northern part of the Siret valley, about $540 \mathrm{~mm}$ of precipitation is recorded annually, whereas on the northern slope of the Bârlad Plateau, these values rise to $615 \mathrm{~mm}$.

In the narrower area of the eastern beech limit, annual precipitation amounts to $560.8 \mathrm{~mm}$ due to the lower elevation (150-250 $\mathrm{m}$ a.s.1.) and active foehn processes at the contact between the plateau and Jijia hilly plain subunits. During the rainy years, the amount of water can exceed $700 \mathrm{~mm}$, and during dry years it falls below $400 \mathrm{~mm}$ - figure 8 . Even the wettest years record insufficient rainfall for beech growth.

In the M-J interval, when beech already enters its vegetation season, average precipitation amounts to $225.5 \mathrm{~mm}$ (40.2\% of the annual amount); there are also years when over $300 \mathrm{~mm}$ of precipitation are recorded during the $\mathrm{M}-\mathrm{J}$ months, and years when precipitation falls below $100 \mathrm{~mm}$.
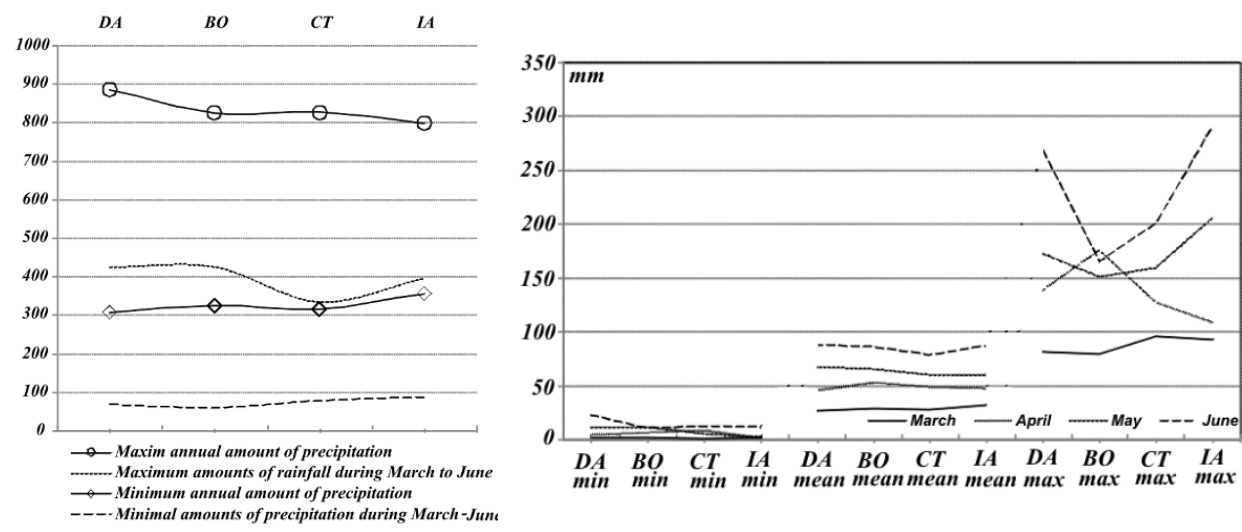

Figure 8 Maximum and minimum annual precipitation values in the M-J interval on the eastern beech limit, NE Romania (1960-2010).

Figure 9 Variability of monthly precipitation sums (minimum, average and maximum values) in the M-J interval on the eastern beech limit, NE Romania (1960-2010).

Although the May-June interval is regarded as the rainiest of the entire year, the amount of precipitation required for beech growth is not sufficient (water balance equals $-50 \mathrm{~mm}$ at Botoșani, $-55 \mathrm{~mm}$ at Cotnari, $-60 \mathrm{~mm}$ at Iași, based on pluviometric data from 1961 to 2017). Precipitation deficiency is compensated to a certain extent by underground water, fed by snow layer melting in March-April. However, these water reserves are limited. Any small variation below the average of available water, either from precipitation or snow melt, leads to low beech growth rates. 


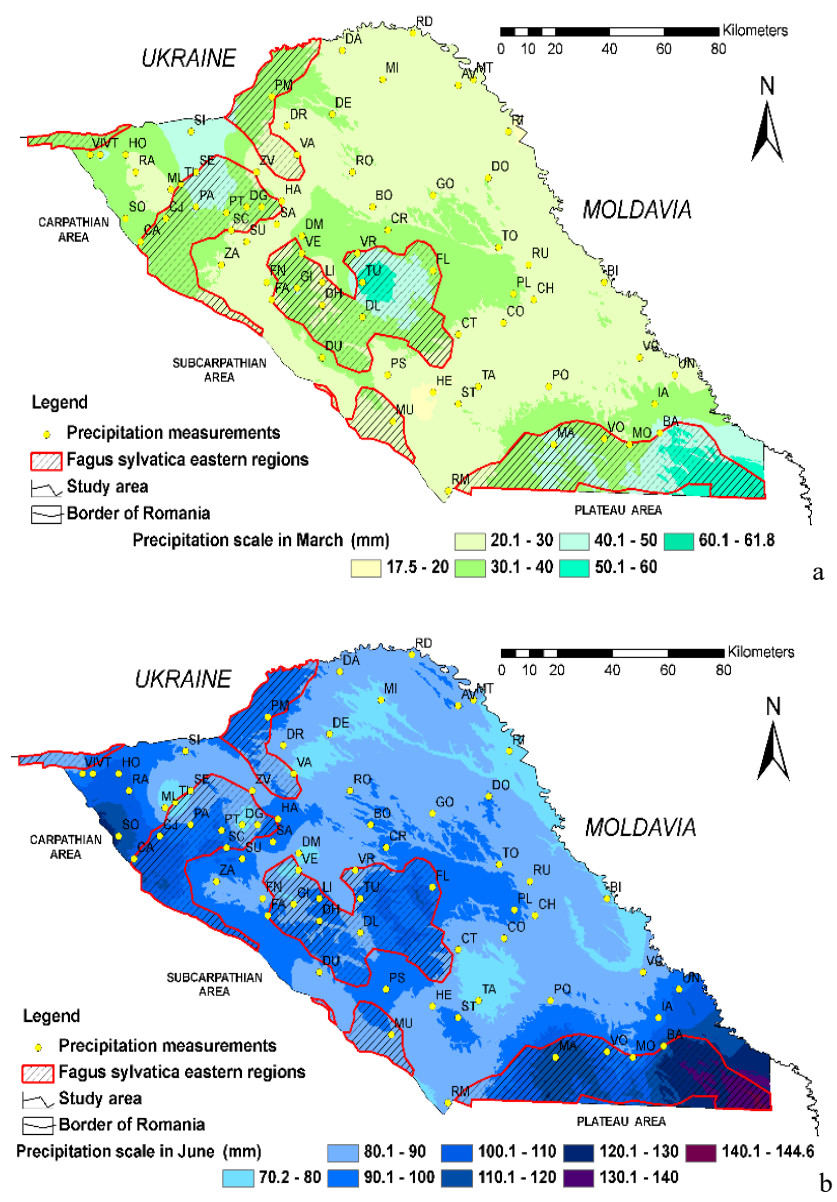

Figure 10a, b

Compared to the average values, the actual annual precipitation amounts ranged between the maximum of $885.9 \mathrm{~mm}$ at Darabani, $796.3 \mathrm{~mm}$ at Iași, and minimum of $306.2 \mathrm{~mm}$ at Darabani, $355 \mathrm{~mm}$ at Iași - Figure 8. In the M-J interval, the highest precipitation amounts were $422.8 \mathrm{~mm}$ at Botoşani, and the lowest $59.2 \mathrm{~mm}$ at the same station - Figure 8. Significant negative precipitation anomalies are unfavorable for beech growth, especially if the climate matrix also includes other restricting elements. 


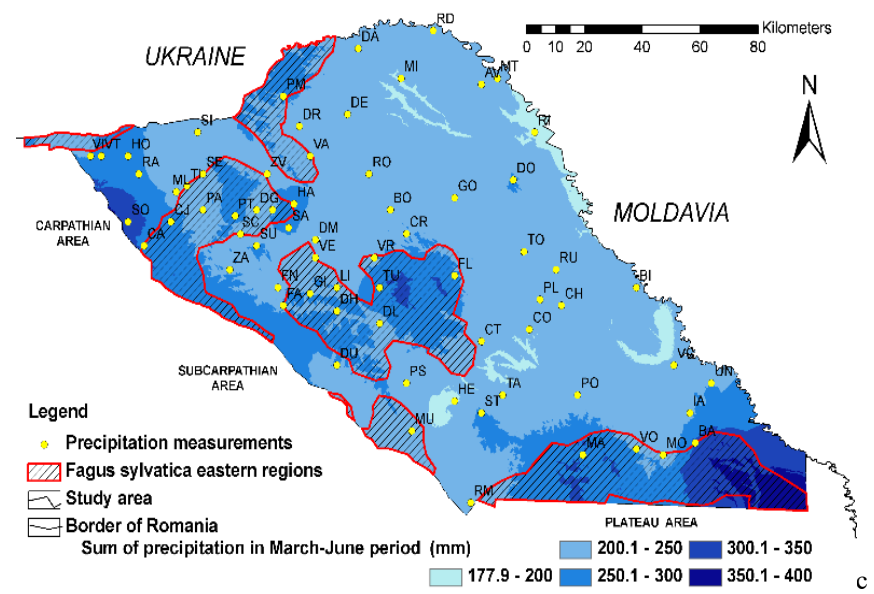

Figure 10 Spatial distribution of the monthly precipitation sums for: a) March, b) June, c) M-J interval (1960-2010).

Minimum monthly precipitation sums in the M-J interval on the eastern beech limit did not exceed $2.2 \mathrm{~mm}$ in March and $23.1 \mathrm{~mm}$ in June, the monthly average sums ranged between $32.1 \mathrm{~mm}$ in March and $88.3 \mathrm{~mm}$ in June, and the maxima were of $95.6 \mathrm{~mm}$ in March and $291.8 \mathrm{~mm}$ in June - Figure 9.

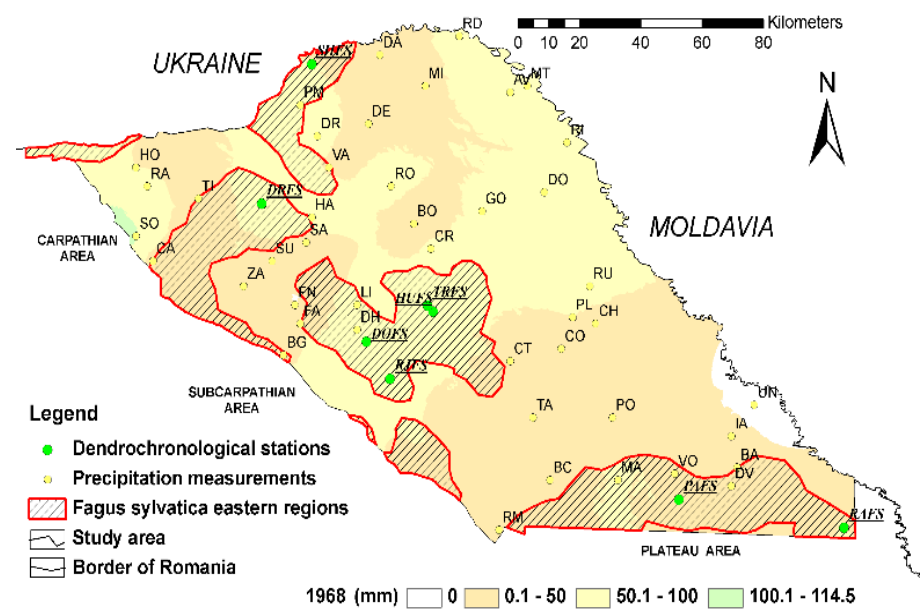

Figure 11. Spatial distribution of average precipitation amounts for the months M-J, year 1968. 


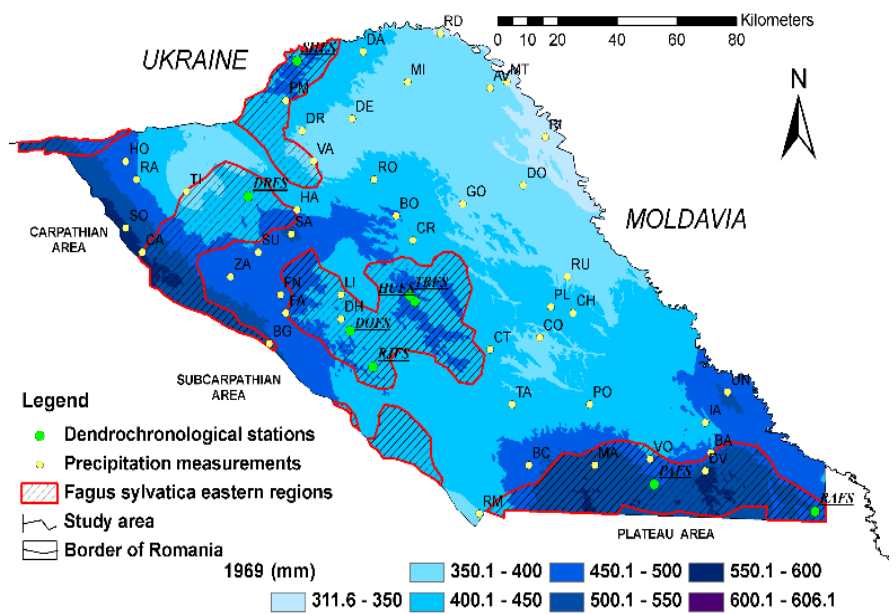

Figure 12. Spatial distribution of average precipitation amounts for the months M-J, year 1969.

Spatial contrasts in terms of precipitation amounts are distinct features of the climate on the eastern beech limit in north-eastern Romania. Precipitation amounts are highly variable on a monthly and annual basis. For the M-J interval, the annual precipitation variability may reach $300-500 \mathrm{~mm}$ (Figures 11 and 12).

Rainfall deficient periods superimposed on warm periods are not beneficial for beech growth.
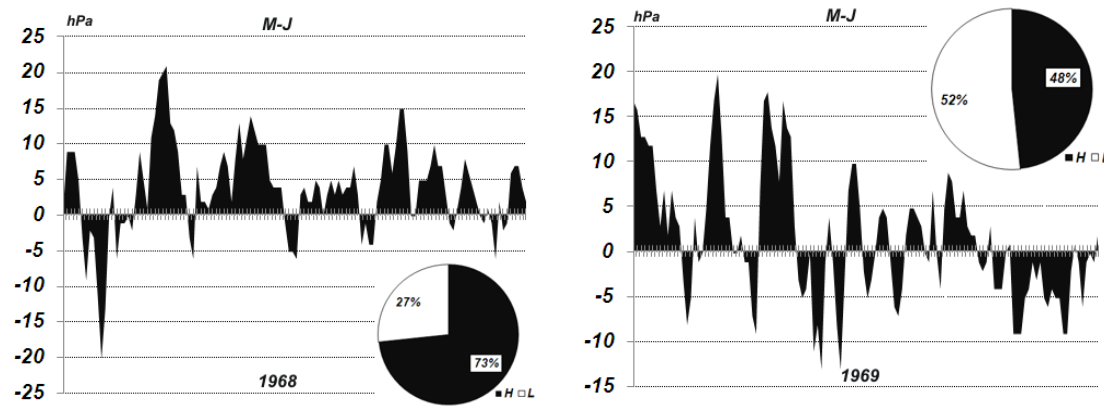

Figure 13 Inter-daily variability of positive and negative pressure anomalies in the M-J months in 1968 and 1969.

Years (e.g. 1968) with M-J precipitation lack (deficiency) annual growth indices in beech reveal low wood accumulation. In contrast, a higher biomass 
production was identified when the M-J intervals were characterized by high precipitation amounts (e.g., 1969) (Roibu, 2010, Roibu et al., 2017).

We have then analyzed the synoptic data for the M-J interval in the two contrasting years, i.e., 1968 and 1969, and corroborated the information with beech growth indices. We found that the M-J interval of 1968 was characterized by the largest negative precipitation anomalies based on the $\mathrm{z}$ score index (-2.66), whilst the M-J interval of 1969 by the largest positive anomalies (+2.69). Using the ground-level pressure data for our study area, extracted from daily maps available online (www.wetterzentrale.de), we derived the inter-daily variation of pressure anomalies in the M-J interval (Figure 13).

Results show that the low precipitation amounts recorded in the M-J interval in 1968 is confirmed by the predominance (73\%) of high atmospheric pressure systems. Conversely, the high precipitation amounts recorded in the M-J interval in 1969 are explained by the predominance $(52 \%)$ of cyclonic systems.

All these particularities in precipitation regime of the study area, which negatively affect beech growth, overlap a wider-scale precipitation regime with no clear spatial trends (Table 6).

Table 6 Monthly (M-J interval) and annual averages of the Sen's slope estimates for precipitation at several meteorological stations located near or on the eastern beech limit in north-eastern Romania (1961-2017). Sen's slope estimates were obtained by Mann Kendall test.

\begin{tabular}{cccccc}
\hline Precipitations & Rădăuți & Suceava & Botoșani & Cotnari & Iași \\
\hline M & 0.025 & 0.017 & 0.000 & 0.128 & -0.090 \\
A & -0.097 & -0.059 & 0.024 & 0.176 & 0.008 \\
M & -0.044 & -0.267 & -0.176 & -0.067 & -0.068 \\
J & -0.162 & -0.193 & -0.451 & 0.410 & -0.562 \\
Annual & -0.394 & -0.005 & 0.646 & 1.526 & -1.430 \\
\hline
\end{tabular}

The difference between M-J precipitation amounts and the potential and actual evapotranspiration in our study area shows a precipitation deficit that we render as important (an average of about $100 \mathrm{~mm}$ for the stations BO, CT, IS) (Figure 14).

Our results indicate a decrease in annual precipitation during the M-J months over the 1961-2017 year interval. Similar results were obtained by Potop et al. (2012) and Mihăilă and Briciu (2012). The values obtained by applying the Mann Kendall test do not indicate this pattern at all stations, and do not yet show a clear statistical significance.

The precipitation deficit that characterizes the May-June interval (Figures 15 and 16) places these months at the boundary between semi-wet and 
semi-arid, based on the classifications of Thomas et al., (1993) and McKee et al. (1993). Such a typological classification shows that the water balance is deficient in our study area during the months when available water is very important for the growth of this species.

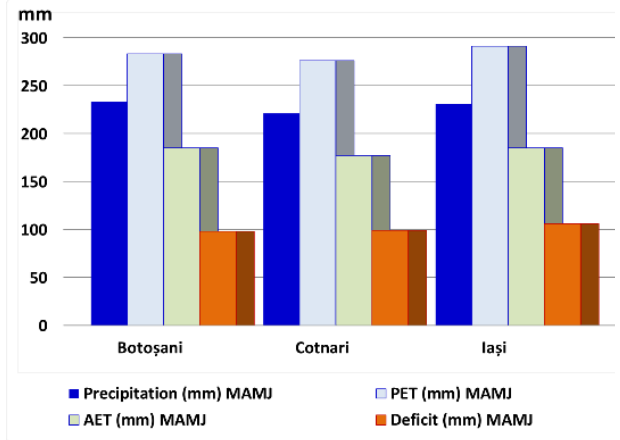

Figure 14 Water balance on the eastern beech limit for the M-J months (19612017).

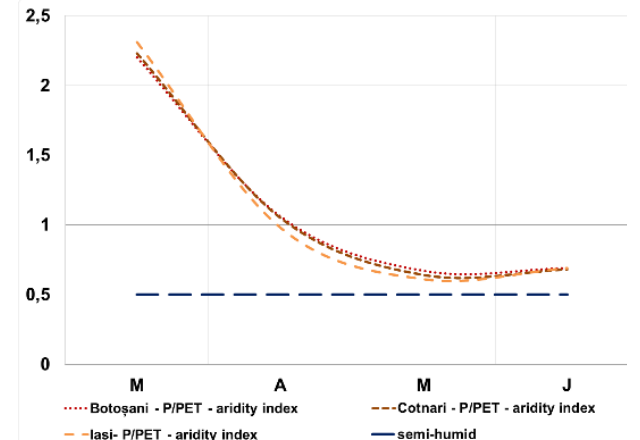

Figure 15 Inter-monthly variability of aridity index on the eastern beech limit for the M-J months (1961-2017).

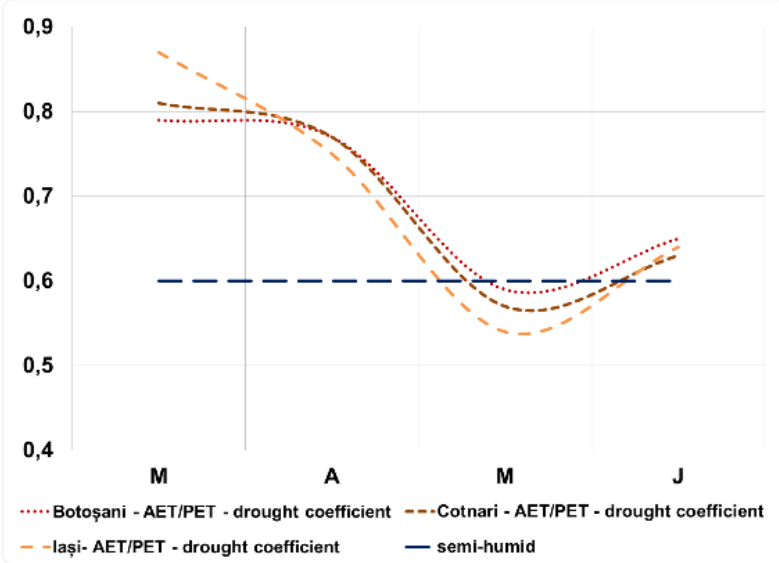

Figure 16 Inter-monthly variability of drought coefficient on the eastern beech limit for the M-J months (1961-2017).

Thus, we note the vulnerability of beech in relation to regional water balance in the M-J months. A similar relationship can be also inferred from the averaged values of the climatic parameters summarized in Table 7.

Given that relatively low precipitation and high evapotranspiration (due to the relatively high temperatures) are limiting factors in the eastward 
expansion of beech forests in north-eastern Romania, an efficient assessment of the frequency of occurrence and intensity of dry conditions and drought phenomena can be achieved using the standardized precipitation index (SPI) developed by McKee in 1993.

Table 7 Summary of the main climatic parameters influencing water balance on the eastern beech limit (calculations performed according to the model proposed by Thornthwaite in 1948, with reference to the 1961-2017 interval)

\begin{tabular}{|c|c|c|c|c|c|c|c|c|c|c|c|c|c|c|c|}
\hline \multirow{2}{*}{ Parameter } & \multicolumn{5}{|c|}{ Botoșani (1960 - 2017) } & \multicolumn{5}{|c|}{ Cotnari $(1960-2017)$} & \multicolumn{5}{|c|}{ Iași (1960 - 2017) } \\
\hline & III & IV & V & VI & $A n$ & III & IV & V & VI & $A n$ & III & IV & $\mathbf{V}$ & VI & $A n$ \\
\hline Precipitation (mm) & 30 & 53 & 65 & 85 & 569 & 29 & 50 & 60 & 82 & 537 & 32 & 50 & 61 & 88 & 572 \\
\hline PET (mm) & 14 & 50 & 96 & 123 & 668 & 13 & 47 & 95 & 121 & 666 & 14 & 51 & 99 & 127 & 689 \\
\hline AET (mm) & 11 & 38 & 57 & 79 & 402 & 11 & 36 & 54 & 76 & 381 & 12 & 38 & 54 & 81 & 388 \\
\hline Deficit (mm) & 3 & 12 & 39 & 44 & 266 & 2 & 11 & 41 & 45 & 285 & 2 & 13 & 45 & 46 & 301 \\
\hline $\begin{array}{l}\text { AET/PET - drought } \\
\text { coefficient }\end{array}$ & 0.79 & 0.77 & 0.59 & 0.65 & 0.73 & 0.81 & 0.77 & 0.57 & 0.63 & 0.70 & 0.87 & 0.75 & 0.54 & 0.64 & 0.71 \\
\hline P/PET - aridity index & 2.20 & 1.06 & 0.67 & 0.69 & 6.19 & 2.23 & 1.05 & 0.64 & 0.68 & 6.05 & 2.31 & 0.98 & 0.61 & 0.69 & 10.6 \\
\hline
\end{tabular}

Trends in annual and M-J variability of the SPI index show an evolution between moderately dry and moderately-wet patterns - when the analysis is performed for 365-day intervals, and between slightly / very dry and slightly / very wet patterns when the analysis is performed for the months March-June. The frequency of time intervals with negative SPI values is significant, which shows that in some years and on the long term, beech experiences unfavorable growth conditions. Successive dry and very dry years and M-J intervals (19992004) were already shown as highly unfavorable for beech growth (Table 2 , after Roibu, 2010).

Beech growth indices show that over the last decade there is a decrease in the intensity of bioaccumulation processes of beech the study area, which can be attributed to the increasing occurrence of dry intervals at the beginning of the vegetation season.

By comparing our results with the data obtained by Fang and Lechowicz (2006), we note that in north-eastern Romania, beech grows in temperature conditions that significantly deviate from the conditions required for the optimal growth of this species.

Our results highlight for the study area a high degree of continentalism, annual precipitation which significantly falls below optimum levels for beech growth, coupled with high potential evapotranspiration. For example, the annual water balance calculated using the Thornthwaite (1948) method for the 1961-2017 interval is deficient at Botoșani $(-99 \mathrm{~mm})$, Cotnari $(-129 \mathrm{~mm})$ and Iași (-117 mm).

The influence of M-J precipitation amounts on annual ring growth is clearly highlighted in our dendrochronological series. The shortage or lack of 
precipitation in the spring - summer months is considered the main limiting factor of beech expansion eastward of the study area (Roibu, 2010).

\section{Conclusions}

Our results confirm that weather conditions during the March-June (MJ) interval are the main climatic factor limiting beech expansion eastward of the study area. These conditions include atmospheric dryness, reduced nebulosity, low/absence of precipitation due to the persistence of anticyclonic pressure systems, cumulated with high temperature and evapotranspiration values. Negative temperatures in the April-June interval are, next to precipitation deficiency, another limiting factor for beech growth and expansion in north-eastern Romania. Our findings thus add valuable information to previous research which has shown that beech growth is secondarily but relevantly influenced by the lack of precipitation added to high temperatures in the vegetation season of the preceding year.

\section{References}

1. Alexandrov V., Gajdusek M.F., Knight C.G., Yotova A. (eds.) (2010), Global environment change: challenges to science and society in SE Europe, Springer, 278 p. DOI 10.1007/978-90-481-8695-2

2. Alsamamra H., Ruiz-Arias J. A., Pozo-Vázquez D., Tovar-Pescador J.

(2009), A comparative study of ordinary and residual kriging techniques for mapping global solar radiation over southern Spain, Agric. and F. Meteo., Vol. 149, Issue 8, 1343-1357. https://doi.org/10.1016/j.agrformet.2009.03.005

3. Awaya Y., Tanaka K., Kodani E., Nishizono T. (2009), Responses of a beech (Fagus crenata Blume) stand to late spring frost damage in Morioka, Japan, Forest Ecology and Management, Volume 257, Issue 12, 2359-2369 https://doi.org/10.1016/j.foreco.2009.03.028

4. Biondi F., Visani S. (1996), Recent developments in the analysis of the italian tree-ring network with emphasis on Europeen beech (Fagus sylvatica L.). Tree rings, Envoronment and Humanity Radiocarbon, 713-725

5. Boer G. J. and Lambert S. J. (2001), Second order space-time climate difference statistics, Clim. Dyn., 17, 213-218

6. Boroneanț C., Potop V., Caian M., Soukup J. (2013), Using various visualization techniques to outline vulnerability to drought in the Republic of Moldova, G. N. 2: $97-108$

7. Bréda N., Huc R., Granier A., Dreyer E. (2006), Temperate forest trees and stands under severe drought: a review of ecophysiological responses, adaptation processes and long-term consequences, Ann. Sci. Forest. 63: 625-644 https://doi.org/10.1051/forest:2006042 
8. Chira D., Dănescu F., Geambașu N., Roșu C., Chira Florentina, Mihalciuc V., Surdu Aurelia (2005), Caracteristicile declinului la fag în 2001-2004, An. ICAS 48: 3-20, 115-134

9. Chira D., Dănescu F., Roșu C., Chira Florentina, Mihalciuc V., Surdu Aurelia, Nicolescu N.V. (2003), Some recent issues regarding the european beech decline in Romania, Anale I.C.A.S., 46, 155-166

10. Dittmar C., Zech W., Elling W. (2003), Growth variations of Common beech (Fagus sylvatica L.) under different climatic and environmental conditions in Europe - a dendroecological study. For. Ecol. Man. 173: 63-78 https://doi.org/10.1016/S0378-1127(01)00816-7

11. Dobbertin M. (2005), Tree growth as indicator of tree vitality and of tree reaction to environmental stress: a review, European Journal of Forest Research 124: 319-333. https://doi.org/10.1007/s10342-005-0085-3

12. Fang J., Lechowicz M. (2006), Climatic limits for the present distribution of beech (Fagus L.) species in the word, Journal of Biogeography, 33, 1804-1819 https://doi.org/10.1111/j.1365-2699.2006.01533.x

13. Fotelli M.N., Nahm M., Radoglou K., Rennenberg H., Halyvopoulos G., Matzarakis A. (2009), Seasonal and interannual ecophysiological responses of beech (Fagus sylvatica) at its south-eastern distribution limit in Europe, FEM. 257: 1157- 1164. https://doi.org/10.1016/j.foreco.2008.11.026

14. Kramer K., Degen B., Buschbom J., Hickler T., Thuiller W., Sykes M. T., deWinter W. (2010), Modelling exploration of the future of European beech (Fagus sylvatica L.) under climate change. Range, abundance, genetic diversity and adaptive response. Forest Ecology and Management 259: 2213-2222. https://doi.org/10.1016/j.foreco.2009.12.023

15. Lebourgeois F., Bréda N., Ulrich E., Granier A. (2005), Climate-treegrowth relationships of European beech (Fagus sylvatica L.) in the French Permanent Plot Network (RENECOFOR). Trees 19: 385-401. DOI 10.1007/s00468-004-0397-9

16. McKee T. B., Doesken N. J., and Kleist J. (1993), The relationship of drought frequency and duration to time scales, Proceedings of the Eighth Conference on Applied Climatology, Boston, MA: American Meteorological Society

17. Michelot A., Bréda N., Damesin C., Dufrêne E. (2012), Differing growth responsest o climatic variations and soil water deficits of Fagus sylvatica, Quercus petraea and Pinus sylvestris in a temperate forest, Forest Ecology and Management 265: 161-171. https://doi.org/10.1016/j.foreco.2011.10.024

18. Mihăilă D. (2006), Câmpia Moldovei. Studiu climatic, Edit. Univ. Suceava, 465 p

19. Mihăilă D., Bistricean P.I., Lazurca Liliana Gina, Briciu A.-E. (2017), Climatic water deficit and surplus between the Carpathian Mountains and the Dniester River (1961-2012), Environ Monit Assess, 189: 545, DOI 10.1007/ s10661-017-6253-3

20. Mihăilă D., Briciu A.-E. (2012),Actual climate evolution in the NE Romania. Manifestations and consequences, $12^{\text {th }}$ International Multidisciplinary Scientific GeoConference, SGEM2012 Conference Proceedings/ ISSN 1314-2704, Vol. 4, $241-252$

21. Nahm M., Radoglou K., Rennenberg H., Chalyvopoulos G., Fotelli M.N. 
(2006), Physiological performance of beech (Fagus sylvatica L.) at its southeastern distribution limit in Europe: seasonal changes in nitrogen, carbon and water balance. Plant Biology 8: 52-63. https://doi.org/10.1055/ s-2005-872988

22. Nedealcov M. (2012), Methodological aspects on complex indexes usage in identification and estimation of climatic risks on the R. of Moldova's territory, P.E.S.D. 6(2):69-80

23. Piovesan G., Biondi F., Di Filippo A., Alessandrini A., \& Maugeri M. (2008), Drought-driven growth reduction in old beech (Fagus sylvatica L.) forests of the central Apennines, Italy. Global Change Biology14, $1265-1281$. https://doi.org/10.1111/j.1365-2486.2008.01570.x

24. Piticar A. (2013)Studii privind schimbările climatice recente din nord-estul României, teză de doctorat, Universitatea „Babeş-Bolyai” Cluj-Napoca 222 p

25. Piticar A., Mihăilă D., Lazurca Liliana Gina, Bistricean P.I.., Puţuntică A. \& Briciu A.-E. (2016), Spatiotemporal distribution of reference evapotranspiration in the Republic of Moldova, Theoretical and Applied Climatology, Vol. 120, No. 3-4. DOI 10.1007/s00704-015-1490-2

26. Popa I., Caisîn V. (2015), Răspunsul comparativ al fagului şi stejarului la secetă în Rezervaţia Naturală Codrii (R. Moldova), Bucovina Forestieră 15(1): 45-53

27. Potop V. (2011), Evolution of drought severity and its impact on corn in the Republic of Moldova. Theoretical and Applied Climatology 105(3-4): 469-483 https://doi.org/10.1007/s00704-011-0403-2

28. Potop V., Overcenco A., \& Boroneant C. (2012), Drought variability and its driving factors in the Republic of Moldova, EMS Annual Meeting Abstracts, 9, EMS, 2012-54

29. Roibu C.C. 2010), Cercetări dendrometrice, auxologice şi dendrocronologice în făgete din Podişul Sucevei aflate la limita estică a arealului, Teză de doctorat. USV, $274 \mathrm{p}$

30. Roibu C.C., Popa I. Kirchhefer A. J, Palaghianu C. (2017), Growth responses to climate in a tree-ring network of European beech (Fagus sylvatica L.) from the eastern limit of its natural distribution area, Dendrochronologia, Volume 42, 104-116. https://doi.org/10.1016/j.dendro.2017.02.003

31. Scharnweber T., Manthey M., Criegee C., Bauwe A., Schröder C., Wilmking M. (2011), Drought matters-Declining precipitation influences growth of Fagus sylvatica L. and Quercus robur L. in north-eastern Germany, Forest Ecology and Management 262: 947- 961. https://doi.org/10.1016/j.foreco.2011.05.026

32. Tănasă I. (2011), Clima Podişului Suceava - Fenomene de risc, implicaţii în dezvoltarea durabilă, Teză de doctorat, Universitatea Ştefan cel Mare, Suceava

33. Thomas B., McKee T.B., Nolan J. D. and Kleist J. (1993), The relationship of drought frequency and duration to time scales, Eighth Conference on Applied Climatology, 17-22 January 1993, Anaheim, California

34. Venkatram A. (1988), On the use of kriging in the spatial analysis of acid precipitation data, Atmospheric Environment, 22(9): 1963-1975

35. Vicente-Serrano S.M., Beguería S., López-Moreno J.I. (2010), A multiscalar drought index sensitive to global warming: the standardized precipitation evapotranspiration index. Journal of Climate 23(7): 1696-1718. https://doi.org/10.1175/2009JCLI2909.1 
42 Dumitru Mihăilă, Andrei Emil Briciu, Cătălin Constantin Roibu, Petruţ Ionel Bistricean

36. Vicente-Serrano S.M., Beguería S., Lorenzo-Lacruz J., Camarero J.J., López-

Moreno J.I., Azorin-Molina C., Revuelto J., Moran-Tejeda E., Sanchez-

Lorenzo A. (2012), Performance of drought indices for ecological, agricultural, and hydrological applications, Earth Interactions 16(10): 1-27.

https://doi.org/10.1175/2012EI000434.1

37. ***www.wetterzentrale.de

(c) (1) (8)
(C) 2020 by the authors. Licensee UAIC, Iasi, Romania. This article is an open access article distributed under the terms and conditions of the Creative Commons Attribution (CC BY-NC-ND) license (https:// creativecommons.org/licenses/by-nc-nd/4.0). 